Abstracta Iranica Abstracta Iranica

Revue bibliographique pour le domaine irano-aryen

Volume 27 | 2006

Comptes rendus des publications de 2004

\title{
Ensān-šenāsī-ye šahrī. Tehrān, Našr-e Ney, 1383/2004, 608 p. [Anthropologie urbaine]
}

\section{Hosseyn Mirzaï}

\section{Q OpenEdition}

1 Journals

\section{Édition électronique}

URL : http://journals.openedition.org/abstractairanica/6670

DOI : 10.4000/abstractairanica.6670

ISSN : 1961-960X

Éditeur :

CNRS (UMR 7528 Mondes iraniens et indiens), Éditions de l'IFRI

\section{Édition imprimée}

Date de publication : 15 mai 2006

ISSN : 0240-8910

Référence électronique

Hosseyn Mirzaï, «Ensān-šenāsī-ye šahrī. Tehrān, Našr-e Ney, 1383/2004, 608 p. [Anthropologie urbaine] », Abstracta Iranica [En ligne], Volume 27 | 2006, document 377, mis en ligne le 02 janvier 2007, consulté le 25 septembre 2020. URL : http://journals.openedition.org/abstractairanica/6670 ; DOI : https://doi.org/10.4000/abstractairanica.6670

Ce document a été généré automatiquement le 25 septembre 2020.

Tous droits réservés 
Ensān-šenāsī-ye šahrī. Tehrān, Našr-e Ney, 1383/2004, 608 p. [Anthropologie urbaine]

Hosseyn Mirzaï 
1 Un gros travail de base - depuis l'étude des origines de la ville, son évolution au cours de l'histoire, jusqu'à la méthodologie de l'étude anthropologique sur le sujet - vient d'être effectué par l'A. Ce travail comble l'une des multiples lacunes de l'anthropologie en Iran, et jette la base de l'anthropologie urbaine.

2 Avant d'aborder au chap. 4 l'étude proprement dite des villes, l'A. développe successivement au cours d'une introduction et des trois premiers chapitres du livre des thèmes tels que l'origine des différentes villes du monde et les divers aspects de leur évolution, pour passer ensuite aux théories de l'anthropologie urbaine. Il finit ensuite avec la méthodologie propre à l'étude historico-anthropologique des villes et à leurs caractéristiques géographiques, historiques, démographiques, spatiales, culturelles, administratives, etc., $\ldots$

3 Nous nous intéressons ici plus particulièrement au chapitre de l'ouvrage intitulé : « Une introduction à l'anthropologie urbaine en Iran ». L'A., après avoir tracé un historique des études déjà menées sur la ville en Iran et mentionné les sources anciennes et nouvelles de ces études avant et après l'Islam, décrit les formes d'habitation et d'urbanisation au point de vue aussi bien sociologique qu'anthropologique, traditionnel que moderne, ... pour arriver à l'analyse des structures tant générales que particulières des espaces urbains sacrés et profanes, professionnels, communicationnels ainsi que la relation espace-temps, espace-pouvoir, espace-économie, etc. L'étude des sous-groupes culturels, des expressions et typologies urbaines, des ethnies, des langues, des fonctions écologique et sémiologique est également réalisée...

4 Quatre articles dont deux sur l'Iran, concernant la pensée sociale de l'architecture et le modèle de consommation de l'espace chez les Iraniens ainsi que la liste des instituts et publications concernant l'architecture et l'urbanisation en Iran viennent étayer le regard neuf que Nāṣer Fakūhī porte sur cet aspect de la vie iranienne.

\section{INDEX}

Thèmes : 16.1. Iran

\section{AUTEURS}

HOSSEYN MIRZAİ

Université de Téhéran 